\title{
Targeting and International Humanitarian Law in Afghanistan
}

\author{
Michael N. Schmitt*
}

$\mathrm{E}$ xperience has demonstrated, time and again, that the application of international humanitarian law (IHL) on the battlefield is an exercise of extreme intricacy. No aspect of this body of law has proven more difficult to apply than that governing targeting - the use of force against enemy forces, material and facilities. Combat operations in Afghanistan since October 7, 2001, the date on which the United States and its coalition partners launched Operation Enduring Freedom, have aptly illustrated the complexity of targeting in modern warfare.

This article examines targeting practices during the Operation Enduring Freedom campaign through 2008, with emphasis on US operations. Specifically, it explores the role law played in the calculations of those responsible for planning, approving and conducting "attacks," defined in IHL as "acts of violence against the enemy, whether in offence or defence."1 As will become apparent, their decisions were determined less by law than by either the operational realities of the battlefield or, in a Clausewitzian sense, the policy dictates underpinning the conflict.

Reference is largely to the law applicable in international armed conflict, that is, the law governing hostilities between States. ${ }^{2}$ Although debate continues over whether the terrorist attacks of September 11, 2001 launched a conflict of this

* Charles H. Stockton Professor of International Law, US Naval War College, Newport, Rhode Island. 
Targeting and International Humanitarian Law in Afghanistan

character, ${ }^{3}$ the October 7 coalition strikes against Taliban and terrorist forces based in Afghanistan unquestionably did so, one between Afghanistan and the States participating in the US-led coalition. ${ }^{4}$ Arguably, the conflict became non-international in June 2002, when the Loya Jirga elected Hamid Karzai President of the Transitional Authority, an act which the United Nations recognized as establishing legitimate indigenous governance over a sovereign Afghanistan..$^{5}$ Today, the "war" in Afghanistan comprises a non-international armed conflict between the Afghan government (supported by foreign States) and various armed groups, most notably the remnants of the Taliban and Al Qaeda. ${ }^{6}$

Although the conflict has become non-international, it must be understood that the IHL norms governing attacks during international armed conflicts, on one hand, and non-international armed conflicts, on the other, have become nearly indistinguishable. In particular, the foundational IHL principle of distinction, which requires those involved in hostilities to "at all times distinguish between the civilian population and combatants and between civilian objects and military objectives," applies equally in all conflicts. ${ }^{7}$ That being so, the humanitarian law governing international armed conflict always serves as an appropriate benchmark against which to measure targeting practices.

\section{The Operational Environment}

Afghanistan presented a multifarious environment in which to apply targeting law. ${ }^{8}$ The country's physical and human terrains are of unparalleled complexity. At nearly 650,000 square kilometers, it is roughly the size of Texas. Much of the country is mountainous and few roads or other means of transportation exist. The 5,500kilometer border is ill-defined and porous. These features often compelled US forces to employ airpower in lieu of ground operations. Habitation is widely scattered and predominantly rural, and combatants are seldom distinguishable from civilians by dress. The operational result was an unusually heavy reliance on intelligence, surveillance and reconnaissance (ISR) capabilities, rather than visual identification by an attacker. Complex ethnic and tribal relationships, characterized by shifting alliances, complicated matters. Indeed, Afghans typically have less sense of identity as such than as Tajiks, Pashtuns, Hazaras, Turkmens, Uzbeks or members of other similar groups. In many cases, these ethnic groups straddle borders with Afghanistan's neighbors-Pakistan, Turkmenistan, Uzbekistan, Tajikistan and China.

Perhaps most significantly, Afghanistan's recent history has been one of constant warfare, from the internal conflict and ensuing Soviet invasion of 1979, through the Soviet withdrawal a decade later, and into the war that led to the 1996 
Taliban victory. Defeat of the Taliban by the US-led coalition in late 2001 ushered in the period of hostilities considered here. Many Afghans have known nothing but war, and many have found themselves on both sides of the battle lines at different times. A massive illegal narcotics infrastructure financially fuels these conflicts. Afghanistan is presently the world's largest producer of opium, with an output of eight thousand metric tons in 2008. Since unemployment runs at 40 percent, and in light of a per capita gross domestic product of a meager $\$ 800$, both the drug trade and conflict offer attractive means of subsistence. ${ }^{9}$

As noted, terrain, distance and infrastructure led the coalition forces to rely heavily on air attacks. Political demands for a quick response to September 11, the practical difficulty of rapidly deploying ground forces and fear of repeating the disastrous Soviet experience further led to an emphasis on air operations. ${ }^{10}$ During the initial phase of hostilities, friendly indigenous armed groups, supported by US and coalition special forces, shouldered responsibility for most ground operations. However, once the conflict morphed into a classic insurgency, ground operations assumed increasing importance. Nevertheless, air attack remains a dominant feature of the war in Afghanistan.

\section{Targeting in a Counterinsurgency}

Within months, the conflict in Afghanistan became an insurgency in which traditional methods of warfare no longer sufficed. ${ }^{11}$ As US military doctrine recognizes, the application of force to defeat an insurgency must be but part of a broader strategy that incorporates paramilitary, political, economic, psychological and civic actions.

The application of a purely military approach to irregular warfare [IW] has not proved successful in the past. IW is about winning a war of ideas and perception. Its battles are fought amongst the people and its outcomes are determined by the perceptions and support of the people. The campaign must change the perception and offer viable alternatives, rather than specifically kill an enemy or destroy his resources in isolation. ${ }^{12}$

This reality necessitates carefully measured use of force, lest the complementary components of the strategy suffer. The current US counterinsurgency (COIN) manual accordingly cautions,

[a]ny use of force generates a series of reactions.... Counterinsurgents should calculate carefully the type and amount of force to be applied and who wields it for any operation. An operation that kills five insurgents is counterproductive if collateral damage leads to the recruitment of fifty more insurgents. . . . [Thus,] it is vital for 


\section{Targeting and International Humanitarian Law in Afghanistan}

commanders to adopt appropriate and measured levels of force and apply that force precisely so that it accomplishes the mission without causing unnecessary loss of life or suffering. ${ }^{13}$

Sensitivity to the reverberating consequences of an attack that causes civilian casualties lies at the heart of counterinsurgency strategy, for "using substantial force... increases the opportunity for insurgent propaganda to portray lethal military activities as brutal, [while] using force precisely and discriminately strengthens the rule of law that needs to be established."14

Ultimately, the key is legitimacy with the population, the support of which constitutes the ultimate objective of all counterinsurgencies. The term "legitimacy" unsurprisingly appears 131 times in the COIN manual. In 2008, it was elevated to a "principle of war" for US joint operations. Along with perseverance and restraint, similarly relevant in the context of targeting, legitimacy joined the nine traditional principles: objective, offensive, mass, economy of force, maneuver, unity of command, security, surprise and simplicity. ${ }^{15}$

The legitimacy imperative undergirds US targeting doctrine. As an example, the Air Force requires consideration of the following factors during the "target validation" phase of planning. ${ }^{16}$

- Does the target meet [combined force air component commander] or higher commanders' objectives, guidance, and intent?

- Is the target consistent with [law of armed conflict] and [rules of engagement]?

- Is the desired effect on the target consistent with the end state?

- Is the target politically or culturally "sensitive?"

- What will the effect of striking it be on public opinion (enemy, friendly, and neutral)?

- What are the risks and likely consequences of collateral damage?

- Is it feasible to attack this target? What is the risk?

- Is it feasible to attack the target at this time?

- What are the consequences of not attacking the target?

- Will attacking the target negatively affect friendly operations due to current or planned friendly exploitation of the target? 
Clearly, counterinsurgency targeting planners must be especially sensitive to issues beyond the immediate military utility of a strike and the legal norms governing it.

The collateral damage estimate methodology (CDEM) employed by US forces reflects this sensitivity. ${ }^{17}$ "Collateral damage" refers to incidental injury to civilians and damage to civilian objects caused during an attack on a lawful target. CDEM sets forth "standardized procedures for determining potential collateral damage, options available to mitigate that damage, and approval authorities for strikes based on the anticipated collateral damage during the conduct of operations." ${ }^{18}$ Although the precise parameters of CDEM are classified, in general terms the methodology involves using computer-assisted modeling, intelligence analysis, weaponeering and human vetting to assess likely collateral damage and determine the level at which a preplanned strike must be approved. ${ }^{19}$ It further requires particular caution when attacking dual-use targets, when employing cluster munitions or when civilians are present within military objectives.

\section{The Law of Targeting in Brief}

The law of targeting is, from a theoretical and undeconstructed perspective, fairly straightforward ${ }^{20}$ Consistent with the principle of distinction, attacks may only be conducted against military objectives, including members of the armed forces and other organized armed groups participating in the conflict. ${ }^{21}$ Objects which by "nature, location, purpose, or use make an effective contribution to military action and whose total or partial destruction, capture, or neutralization, in the circumstances ruling at the time, offers a definite military advantage" qualify as military objectives. ${ }^{22}$ By the "use" criterion, civilian objects may become military objectives when the enemy employs them for military ends. Analogously, civilians may be targeted should they "directly participate in hostilities." ${ }^{23}$ Attacks must not be indiscriminate; that is, they must be directed against a specific military objective and may not treat "as a single military objective a number of clearly separated and distinct military objectives located in a city, town, village or other area containing a similar concentration of civilians or civilian objects." ${ }^{24}$

When engaging a lawful target, the attacker may be barred from employing certain weapons. Such restrictions derive either from the customary law forbidding the employment of indiscriminate weapon ${ }^{25}$ and those which cause unnecessary suffering or superfluous injury, ${ }^{26}$ or from specific treaty restrictions, such as the Dublin Treaty on cluster munitions, for States party. ${ }^{27}$

Even assuming a lawful target and permitted weapon, an attacker must take "feasible precautions" to minimize collateral damage. Specifically, "the commander must decide, in light of all the facts known or reasonably available to him, 
Targeting and International Humanitarian Law in Afghanistan

including the need to conserve resources and complete the mission successfully, whether to adopt an alternative method of attack, if reasonably available, to reduce civilian casualties and damage." 28 Considerations include weapon and tactic options, as well as alternative targets that can be attacked to attain a "similar military advantage."

Finally, attacks that violate the principle of proportionality are unlawful. An attack will breach the standard if it is "expected to cause incidental loss of civilian life, injury to civilians, damage to civilian objects, or a combination thereof, which would be excessive in relation to the concrete and direct military advantage anticipated." 29 The rule of proportionality is often misconstrued as either prohibiting "extensive" collateral damage or as a test which balances collateral damage against military advantage. In fact, it bars attack only when no proportionality at all exists between the ends sought and the expected harm to civilians and civilian objects. Restated, the linchpin term "excessive" indicates unreasonable collateral damage in light of the reasonably anticipated military advantage expected to result from the attack. ${ }^{30}$

\section{Law and Targeting in Afghanistan}

That law limits targeting options is self-evident. However, the nature of a conflict equally affects application of the law, sometimes by necessitating policy and operational limitations that exceed those found in international humanitarian law. Nowhere has this dynamic been more apparent than during operations in Afghanistan.

The legitimacy imperative, so prominent in counterinsurgency doctrine, was the driving force behind targeting practices in the conflict. Early high-visibility mistakes drew international attention to the US operations. Of particular note were two mistaken strikes on an International Committee of the Red Cross (ICRC) warehouse in the first month of the conflict and an attack on a wedding party in November ${ }^{31}$ Resultantly, the incentive to avoid future mistakes and, indeed, even lawful collateral damage, grew quickly.

Intent on avoiding unintended harm to the civilian population, commanders imposed strict restrictions on the conduct of operations. For instance, the International Security Assistance Force Commander directed his forces to employ precision munitions whenever possible; humanitarian law imposes no such requirement. Additionally, he directed on-scene commanders to make every effort to ensure houses from which their troops received fire were free of innocent civilians before responding, ${ }^{32}$ even though, as a matter of IHL, returning fire in such circumstances is governed by the rule of proportionality and the requirement to 
take feasible precautions in attack, not by the mere presence of civilians. Further, in 2007 the United States and NATO restricted the use of airstrikes during troops-incontact (TIC) situations, often opting for withdrawal rather than engagement. US forces also increasingly employed small-diameter bombs (low-collateral-damage bombs). Again, IHL would not necessarily mandate such practices.

Despite such efforts, civilian casualties continued to occur. Human Rights Watch estimates that in 2007 over 1,600 civilians were killed in the conflict. Nine hundred fifty died as a result of Taliban and Al Qaeda actions, whereas 434 of the casualties were attributable to US and NATO actions (312 in airstrikes and 113 during ground action). Another fifty-seven died in crossfire between the warring parties and the circumstances surrounding the deaths of 192 were unclear. ${ }^{33}$

President Karzai, struggling with the public-opinion fallout of civilian casualties, repeatedly addressed the issue. Following a particularly tragic attack in 2007 that killed fifty-one civilians, he stated that while "the intention is very good in these operations to fight terrorism ... five years on, it is very difficult for us to continue to accept civilian casualties. ${ }^{34}$ Karzai continues to demand greater care in executing attacks endangering civilians.

A number of obstacles dramatically hindered attempts to avoid collateral damage. The enemy was scattered across the country and often operated in small groups. The non-linear nature of this battlespace meant that operations had to be conducted over vast areas in which the mere position of a group, vehicle or other mobile target seldom served as a reliable indicator of its enemy character. Moreover, because neither the Taliban nor Al Qaeda fielded a classic military force, with corresponding fixed military facilities, coalition forces quickly exhausted known targets, thereby necessitating a shift to fleeting targets, which were harder to identify because of time constraints. Most targeting consequently became "dynamic." In dynamic targeting, targets are passed to aircraft already airborne as hostile forces are identified, thereby limiting the opportunity for comprehensive target analysis, and requiring use of whatever weapons the aircraft happen to be armed with at the time.

The difficulty of identifying the enemy complicated matters. Enemy forces wore no uniforms or other distinctive clothing that allowed immediate visual identification. Merely being armed was an insufficient indicator, as Afghans in remote areas often carry weapons for protection, and because friendly indigenous armed groups were usually indistinguishable from the Taliban and Al Qaeda. General T. Michael Mosely, the combined force air component commander, highlighted the operational murkiness when he noted that "in any given space-ground space-out there, you had regular and unconventional forces, humanitarian assistance guys, 
Targeting and International Humanitarian Law in Afghanistan

maybe regular guys and not one of us in the command authority knew where all those guys were." 35

Determined to avoid incidents which might delegitimize their operations, US and coalition forces imposed wide-ranging targeting restrictions through myriad mechanisms. These included coalition and national rules of engagement (ROE), ${ }^{36}$ no-strike lists (for reasons such as IHL or host-nation sensitivities), restricted target lists (in which attack requires special preapproval, e.g., due to negative cultural implications), individual target folder ${ }^{37}$ restrictions (such as a requirement to use a particular munition or strike a particular "desired point of impact"), Joint Air Operations Plans, ${ }^{38}$ execute orders, ${ }^{39}$ fragmentary orders, ${ }^{40}$ fire support coordination measures ${ }^{41}$ and soldier cards. ${ }^{42}$ The net result was a dense and oft confusing normative environment, one in which IHL played a minor role relative to policy and operational considerations. ${ }^{43}$

Such restrictions deviated measurably from customary practices attendant to attacks on individuals. The traditional approach in conventional conflict is straightforward. Typically, enemy armed forces, including organized armed groups supporting the enemy, are "declared hostile," either at the outset of the conflict or, in the latter case, once their involvement in the conflict becomes evident. Declaring forces hostile operationalizes the principle of distinction, which permits attacks on combatants. It matters not whether the combatants are threatening the attacker, or even whether they represent a potential threat; status alone renders them a lawful target. For instance, an unarmed cook may be attacked on sight if he or she is a member of the armed forces.

By the principle of distinction, civilians may not be attacked unless, and for such time as, they directly participate in hostilities. ${ }^{44}$ Accordingly, although they may not be declared hostile per se, rules of engagement and other targeting guidance allow them to be attacked while engaging in actions that constitute direct participation. Much controversy exists over the reach of the qualifying activities, as well as the meaning of the phrase "for such time." These issues will be dealt with later; the point here is that it is customary for targeting guidance to permit attacks on direct participants.

Beyond declaring forces hostile and incorporating direct participation into the ROE, the third typical form of engagement authority addresses violence with no nexus to the conflict-criminal acts. Soldiers faced with such criminality may employ force consistent with the law of self-defense (and defense of others). Specifically, they may use deadly force to protect themselves and others against an imminent threat of death or serious injury, when less extreme measures are unavailable. ${ }^{45}$ Operationally, the US rules of engagement provide that US military personnel may use force in the face of a hostile act or a demonstration of hostile 
intent. ${ }^{46}$ They may only do so when force is the sole viable option for addressing the situation (principle of necessity). No more force than that required to repel the attack, or prospective attack, is permitted.

This typical three-tiered paradigm was notably altered during operations in Afghanistan. Although targeting practices shifted somewhat over time to meet emerging battlefield realities, in broad terms they have been relatively constant. When the conflict began, the United States and its coalition partners declared no enemy forces hostile, to include the Taliban and Al Qaeda. Instead, the "enemy" had to represent a "likely and identifiable threat" (LIT) before being attacked. Those not meeting this standard could only be engaged if they had committed a hostile act or demonstrated hostile intent, the self-defense rule traditionally employed to respond to actions unconnected to the hostilities. During Operation Iraqi Freedom, by contrast, the Iraqi military was declared hostile from the outset of hostilities. Similarly, "designated terrorist groups" could generally be engaged in the same fashion. ${ }^{47}$

Afghanistan represented the first use of the LIT standard in an armed conflict. It was less permissive than the practice of declaring forces hostile because potential targets had to manifest some degree of threat. Paradoxically, the standard was more permissive than the designated-terrorist-group approach applicable in Iraq because it included no status criterion, i.e., circumstances alone justified engagement even in the absence of intelligence as to membership.

The adoption of this untested approach to engagement authority begs the question of why the standard declaration of forces hostile, combined with direct participation and self-defense ROE, was judged insufficient. Apparently, concern over the liberality of declaring forces hostile, combined with apprehension over the potential for friendly-fire incidents, underpinned the standard. According to one key participant in its development at US Central Command (CENTCOM), the military headquarters for Afghanistan and Iraq operations,

I intentionally designed it to allow the guys in contact (Ground Forces) the ability to engage the "enemy," such as they were, without actually being shot at first, while at the same time limiting the ability of the guys flying at 21,000 feet and 210 knots to drop bombs everywhere they wanted (potentially on our allies). As you know, when we began operations targets (deliberate targets) were intentionally held at the highest levels and this was a way to provide some flexibility to the guy in the field. "Self Defense Plus" is how I describe it. In theory, this gave the Air Force the ability to strike as well (e.g. SAM batteries, anti-aircraft guns, etc). Based on the "OPLAN" I knew there would be people (ally and enemy alike) all over the country that looked exactly the same (white robes/turbans[,] on horses/pickup trucks, etc). 


\section{Targeting and International Humanitarian Law in Afghanistan}

Identification of the enemy was everything during this conflict. There wasn't even a FLOT [forward line of own troops]. Eventually, the best we could do was create small zones/boxes where we could say none of our people were located. You simply couldn't tell who the enemy was from the lawn darts [slang for an F-16] and this was a way of empowering the guys in contact to shoot or call air strikes based upon "Positive Identification" (the totality of the circumstances). And, even with these tight rules the conflict didn't go without incident. ${ }^{48}$

The less candid, but official, CENTCOM explanation focused on the conflict's unique nature. Central Command was intent on maintaining strict control over attacks because it well understood the downside of collateral damage during an insurgency. Recall also the difficulties of verifying targets, both because identification based solely on appearance was problematic and because it was often difficult to determine to which side the various armed groups owed their allegiance at any particular time. With its comprehensive access to ISR assets, and fuller grasp of operational and strategic considerations, CENTCOM believed that it was best situated to distinguish friendly from hostile targets.

Yet, the command realized that a conflict of this magnitude required more than self-defense rules. One scenario cited to justify the new standard involved US forces encountering sleeping Taliban soldiers; another posited aircraft spotting anti-aircraft systems along the route of attack. Self-defense rules alone would not permit attack in such situations, and it clearly would make no sense for soldiers in the field or airborne aircraft to have to "call home" for engagement authorization, merely because these lucrative targets were neither committing a hostile act nor demonstrating hostile intent. For CENTCOM, the answer lay in the LIT standard. ${ }^{49}$

The level of certainty required to determine that a target qualified as a likely and identifiable threat was also a novel feature, at least in ground operations. Likely and identifiable threat required more than merely "suspicious people in a questionable location." ${ }^{50}$ Rather, the rules of engagement mandated positive identification (PID) of the target as a threat before attacking it. Previously, this standard had only been applied in the no-fly-zone-enforcement context of Operations Northern and Southern Watch. ${ }^{51}$ Afghanistan represented its first use in ground operations, and it unsurprisingly caused confusion. The meaning of PID was eventually clarified in an unclassified format during Operation Iraqi Freedom on the Combined Forces Land Component ROE Card: "PID is a reasonable certainty that the proposed target is a legitimate military target." ${ }^{22}$ Interestingly, PID had meant something much more in the no-fly-zone context-almost a no-mistakes standard. ${ }^{53}$

Accounts from soldiers and airmen, as well as judge advocates, indicate that LIT generated confusion, in great part because it was not a standard to which combat 
forces had trained. Numerous subordinate commands urged CENTCOM to issue guidance. ${ }^{54}$ The new terminology also elevated form over substance, at least to an extent. For instance,

[r] eservations of targeting authority to higher levels made it extremely important for team members calling for fires to use the right terms to avoid any delays. In addition to using terms like "positively identified" and "likely and identifiable threat" in the request, the team members needed to indicate the situation requiring the fires so that the approval was obtained at the most immediate level possible..$^{55}$

One US officer cut to the chase: "When lawyers can easily argue about what [LIT] means or doesn't mean as far as engaging targets, we have failed[,] because the 21year-old corporal doesn't have the luxury of such an academic exercise." 56

Likely and identifiable threat represented a standard exceeding that required by the relevant norms of international humanitarian law. Most significantly, it rejected the universally accepted premise that combatants, whether members of the armed forces or of other organized armed groups, can be attacked on sight. Under IHL, their mere status as combatants rendered them targetable. By contrast, act (or imminent act) replaced status in the LIT standard.

LIT is a genre of the direct participation in hostilities - one without an express "for such time" component. This should be unsurprising, since the absence of classic conventional operations by the Taliban and $\mathrm{Al}$ Qaeda, combined with the difficulty of identifying fighters as members of a particular group, meant that application of the direct-participation notion, in some form, was destined to loom large.

As mentioned earlier, disagreement exists over the scope of direct participation. For instance, while all agree that conducting an attack and gathering tactical intelligence qualify, disagreement prevails as to whether directly financing insurgents does. An ICRC-sponsored multiyear project to clarify matters is nearing completion. Although the final interpretive guidance on direct participation has yet to be released, indications are that three cumulative criteria will emerge. ${ }^{57}$

The act in question must first adversely affect (or be likely to do so) enemy military operations or capacity, or harm civilians or civilian objects. Second, there must be a direct causal link between the act and the harm caused the enemy, or the harm must derive from a coordinated military operation of which the act is an integral part. This causality criterion excludes actions that may contribute in some way to the enemy's military efforts, but which do not directly enhance its combat actions. Finally, the act must be designed to negatively affect the enemy in support of its opponent. This belligerent nexus requirement would exclude mere criminality unconnected to the conflict. The LIT standard meets all three criteria: the threat is to 
US forces, the anticipated actions amount to hostile activity and the forces acting are not mere criminals.

The absence of a "for such time" element in LIT raises several legal issues. Before discussing them, it is useful to recall that they are not raised as to any individuals who are members of an organized armed force, for, as noted, members of such groups may be attacked regardless of whether they are directly participating. ${ }^{58}$ There is no temporal issue-as a matter of law-vis-à-vis them.

Those who are not members of an organized armed group, but meet the direct participation scope threshold, may only be attacked "for such time" as they directly participate in the hostilities. The notion of "for such time" is the source of much contention. The ICRC Commentary to the relevant provision of Additional Protocol I, Article 51.3, provides that direct participation includes "preparations for combat and return from combat," but that "[o]nce he ceases to participate, the civilian regains his right to the protection ...." ${ }^{59}$ Individuals who have not set out to attack their enemy are immune from attack; those who manage to make it home following an operation regain civilian protection until they set out on another operation. Certain experts of the working group on direct participation embraced the strict approach set forth in this non-binding commentary.

Other experts point out that this narrow approach creates a "revolving door" through which the direct participant passes as he or she begins and completes each mission. ${ }^{60}$ They propose an alternative which locks the door after exit: once an individual has opted into the hostilities, he or she remains targetable until unambiguously opting out. Opting out can occur either through extended nonparticipation demonstrating an intention to desist from further involvement, or an affirmative act of withdrawal. Although it may be difficult to determine whether a potential target has opted out, since the individual did not enjoy any privilege to engage in hostilities in the first place, it is reasonable that he or she bear the risk that the other side is unaware of withdrawal.

This is the better interpretation of direct participation. In international humanitarian law, gray areas must be interpreted in light of the law's underlying purposes-achieving balance between military necessity and humanitarian concerns.$^{61} \mathrm{~A}$ revolving door would throw off this balance. It would frustrate combatants charged with combating the direct participants, and combatants frustrated with legal norms constitute a risk to the civilian population. Additionally, the restrictive approach would paradoxically create a situation in which those entitled to use force-lawful combatants-would enjoy less protection than those not so entitled but nevertheless doing so; the former could be attacked at any time, whereas the latter could only be attacked while deploying to and from an operation and 
during the operation itself. From a military necessity perspective, enemy direct participants would unacceptably enjoy a temporal sanctuary. ${ }^{62}$

The LIT standard runs counter to the revolving-door interpretive approach. For instance, the approach begs the question of how one responds to the sleepingfighters scenario posed by those responsible for LIT's adoption. By strict application of the revolving-door approach, the sleeping fighters could not be engaged. LIT imposes no such constraint. Albeit sleeping, the fighters are a likely and identifiable threat. There need be no debate as to whether their sleeping falls within the confines of deploying to or from an operation. By contrast, the alternative liberal interpretation of direct participation tracks LIT neatly. Both allow attack in this and similar situations in which the direct participant is taking a tactical pause. Indeed, these are precisely the sorts of scenarios posed by critics of the revolving-door approach to convincingly point out its impracticality.

As can be seen, LIT is roughly comparable to the liberal standard of direct participation. ${ }^{63}$ Yet, beyond questions as to the scope of the standard lies the issue of certainty. With LIT, individuals must be positively identified as likely threats before being attacked. This requirement poses a number of practical and legal questions. Central among them is the requisite type and degree of certainty. What does "positive" mean in practice? How positive? Beyond a reasonable doubt? More likely than not? And does positive identification mean that the individual in question is likely to be a potential threat or, instead, likely to actually threaten?

Consider the requirement's application on the bewildering battlefield that is Afghanistan. What indicators should suffice in making a positive identification? Perhaps carrying weapons? Yet, many non-participants carried weapons in Afghanistan for self-protection. Perhaps the weapons (e.g., crew-served weapons) evidenced their status as a threat. However, recall that there were friendly indigenous forces armed with the same type of weapons, and that identity and allegiances were difficult to discern. And what type of intelligence should be required to determine that someone was a likely and identifiable threat? Many were available in Afghanistan, but which sufficed? Satellite imagery, unmanned aerial vehicle (UAV) imagery transmitted in real time, human eyes on target, cell phone intercepts, human intelligence? Finally, there is the critical matter of whether positive identification is contextual. That is, does the criterion represent a constant in low- and high-risk environments, or does high risk lower the threshold necessary for positive identification? In Afghanistan, both environments existed at various times and places.

Uncertainty is hardly a novel phenomenon on the battlefield. That being so, States have tended to mandate the only level of certainty that is practicable in the fog of war-would a reasonable warfighter in the same circumstances hesitate to act? The US position is representative. The Commander's Handbook on the Law of 
Targeting and International Humanitarian Law in Afghanistan

Naval Operations provides that "[c] ombatants in the field must make an honest determination as to whether a particular person is or is not taking a direct part in hostilities based on the person's behavior, location, and attire, and other information available at the time." 64

International humanitarian treaty law also addresses battlefield uncertainty. Article 50.1 of Additional Protocol I provides that "in case of doubt whether a person is a civilian, that person shall be considered to be civilian." ${ }^{65}$ Obviously, the article does not rule out doubt altogether. This is clear from the ICRC Commentary on the provision, which notes, in an example particularly appropriate to Afghanistan, "if combatants do not clearly distinguish themselves from the civilian population..., this could result in a weakening of the immunity granted civilians and the civilian population." 66 Such weakening could occur only if engagement in the face of some doubt was contemplated by the commentary. The UK understanding accompanying its ratification of the Protocol similarly adopts a contextual reading. It states that "the rule... applies only in cases of substantial doubt still remaining after [the required assessment of the attack], and [it does not override] a commander's duty to protect the safety of troops under his command or to preserve his military situation, in conformity with the other provisions of the protocol." ${ }^{67}$ The determinative term is "substantial." Finally, the ICRC's Customary International Humanitarian Law study reasonably finds that "it is fair to conclude that when there is a situation of doubt, a careful assessment has to be made under the conditions and restraints governing a particular situation as to whether there are sufficient indications to warrant attack. One cannot automatically attack anyone who might appear dubious." 68 Use of the phrase "sufficient indications" suggests that absolute certainty was not required.

It is unclear what LIT required beyond IHL's "reasonable warfighter in same or similar circumstances" threshold. Its positive-identification requirement, absent clear explication to the contrary, could be interpreted as suggesting that the established IHL frame of reference had been rejected in lieu of a more restrictive standard. But, if so, how? Complicating matters even further is the fact that the concept of positive identification had been adopted in other contexts. For instance, it was adopted for "kill or capture" operations to heighten the preconditions over those applying during a "capture or detain" operation. ${ }^{69}$ So, does PID mean different things in different types of operations? Whatever it does mean, it is clear that PID was at least as restrictive as IHL-in all likelihood more so in application.

Another aspect of targeting in Afghanistan relevant to an IHL analysis was the requirement that attacks be cleared at specified levels of command. As noted by one director of combat operations in the Combined Air Operations Center during Operation Anaconda, 
[t]he ROE was not there to go out and do a conventional fight. Under the rules of engagement for Operation Enduring Freedom, pre-planned strikes, interdiction targets and time-sensitive targets all had to be approved by USCENTCOM; and for the most part, the USCENTCOM/J-2 and legal advisors ... drove what we did and did not target. $^{70}$

His comments exemplified the concerns senior leadership had about operations going awry, even in the remotest of areas. ${ }^{71}$

This raises the issue of approval level. The Anaconda requirements exceeded even those found in the CDEM approval process. Yet, IHL imposes no level of strike approval tied to likely levels of civilian harm. In great part, this is because law is contextual. The degree of lawful civilian harm is determined by reference to the military advantage accruing from the attack in question. "Those who plan or decide upon an attack" must also take feasible (practical in the circumstances) precautions in attack. ${ }^{72}$ In other words, the law lies where it falls—on those planning, approving or executing attacks, whoever they might be. This tightening of the restrictions over and above what IHL required demonstrated the extent to which Afghanistan ROE and CDEM approval levels reflected an understanding that unintended civilian harm can have extra-normative consequences.

The two remaining IHL issues raised by targeting operations in Afghanistan are the principle of proportionality and requirement to take feasible precautions in attack. For a number of practical reasons, proportionality posed few concerns. From an operational perspective, the population was widely dispersed, engagements often occurred in remote areas and no major urban battles took place. Precision munitions were generally available when called for and intelligence, surveillance and reconnaissance assets, particularly unmanned aerial vehicles, could be used to assess and monitor target areas, often in real time.

Counterinsurgency doctrine and practices also minimized the play of the proportionality principle in the conflict. As noted, counterinsurgency doctrine puts a high premium on the avoidance of collateral damage; in Afghanistan, even attacks which were clearly proportionate were often avoided. However, counterinsurgency affects application of the principle in a less obvious fashion.

In conventional operations, proportionality is usually calculated in simple utilitarian terms: civilian lives and property lost versus enemy destroyed and military advantage gained. But in COIN operations, advantage is best calculated not in terms of how many insurgents are killed or detained, but rather which enemies are killed or detained. If certain key insurgent leaders are essential to the insurgents' ability to conduct operations, then military leaders need to consider their relative importance when determining how best to pursue them. In COIN environments, the number of civilian lives lost and property destroyed needs to be measured against how much harm the 


\section{Targeting and International Humanitarian Law in Afghanistan}

targeted insurgent could do if allowed to escape. If the target in question is relatively inconsequential, then proportionality requires combatants to forego [sic] severe action, or seek noncombative means of engagement. ${ }^{73}$

This extract from the COIN manual is overstated. As a matter of law, the military importance of the individuals targeted is always relevant, whether in conventional or counterinsurgency operations. However, the fact that the goal of an insurgency is not attrition of enemy forces means that the military advantage of killing a simple fighter is likely not as high as during attrition warfare, in which victory is achieved through serial destruction of enemy forces.

Reduced to basics, in Afghanistan the operational concern was the mere fact of collateral damage, not whether that damage expected to be caused was excessive relative to military advantage. Rules of engagement so embraced this casualty aversion that the legal principle of proportionality never loomed large.

The case of human shields exemplifies the extent to which, in the context of proportionality, policy and operational considerations swallowed legal requirements. Human Rights Watch has documented the Taliban's widespread use of human shields, ${ }^{74}$ acts which undeniably violated international humanitarian law..$^{75}$

Many experts correctly argue that voluntary shields are direct participants in hostilities who, therefore, do not factor into proportionality calculations. As to involuntary shielding, the practice most prominent in Afghanistan, the weight of opinion holds that its victims remain civilians factored fully into any proportionality analysis. ${ }^{76}$ This approach reflects Additional Protocol I, Article 51.8's caveat that "any violation of ... [inter alia, the provision prohibiting the use of shields] shall not release the Parties to the conflict from their legal obligations with respect to the civilian population and civilians ...." 77

There have been no serious allegations that US forces ever ignored the presence of human shields. On the contrary, CDEM specifically mandates consideration of the presence of human shields; such presence elevates the required approval level. Recall also that rules of engagement and other operational guidelines in Afghanistan often required US forces to withdraw if the enemy was collocated with civilians. Because US forces were already bound by policy and operational requirements exceeding those of IHL, the use of human shields neither complicated application of the existing legal norms nor created pressure for a relaxed interpretation thereof.

Counterinsurgency operations raise a final theoretical question as to proportionality: Does collateral damage directly influence the degree of military advantage accruing from an attack (as distinct from the determination of whether collateral damage is excessive relative to military advantage)? An analogous issue is 
force protection. During Operation Allied Force, NATO aircraft flew at altitudes outside the threat envelope of Federal Republic of Yugoslavia air defenses. Albeit counterfactual, allegations surfaced that this tactic heightened risk to the civilian population. The affair has generated a lively academic debate over whether survival of the aircrew and aircraft should be considered military advantage when making proportionality calculations. ${ }^{78}$

The case of Afghanistan presents the opposite case. If aircrew and aircraft survival enhance military advantage, does the counterproductive nature of collateral damage during a counterinsurgency detract from it? After all, avoidance of collateral damage constitutes an express objective in such conflicts.

Although it is not the place to resolve this complex issue, it is important to understand that, as a rule, military advantage is typically viewed as advantage benefiting friendly operations or hindering the enemy's. ${ }^{79}$ The notion does not extend to winning hearts and minds, a point illustrated by agreement that destroying enemy civilian morale does not qualify as advantage vis-à-vis the definition of military objective. ${ }^{80}$ Rather, military advantage is purely military in nature; there must be some direct contribution to military operations. Political, economic or social advantage does not suffice.

This being so, any assertion that collateral damage should diminish military advantage would have to be supported by a direct nexus to military factors. While true that collateral damage motivates civilian sympathy for the enemy, such general effects are too attenuated. As a general rule, then, collateral damage plays no part in proportionality calculations beyond being measured against the yardstick of excessiveness.

The final area of consideration is the requirement to take precautions in attack. Codified in Additional Protocol I, Article 57, it requires an attacker to minimize collateral damage by taking feasible steps to avoid and, in any event, minimize "incidental loss of civilian life, injury to civilians and damage to civilian objects." Precautions include both target verification and choosing among available targets, weapons and tactics so as to lessen the impact of an attack on the civilian population.

In modern conflicts, critics increasingly condemn targeting operations for failure to comply with the requirement. This phenomenon results, in part, from the fact that the globalized media and non-governmental organizations, employing modern communications technology, have a powerful ability to focus attention on civilian casualties and harm to civilian objects. Collateral damage is easily grasped when viewed in the media; understanding the complexity of mounting a modern attack is not. Thus, perceptions can become distorted. 


\section{Targeting and International Humanitarian Law in Afghanistan}

Further, the availability of advanced intelligence, surveillance and reconnaissance assets, especially UAVs and precision weaponry, such as the small-diameter bomb, ${ }^{81}$ has created the false impression that technology makes "zero collateral damage" attacks possible. The result is a recurring sense that failure to take precautions is the only possible explanation for civilian damage, injuries and deaths. ${ }^{82}$

Reports on US and coalition operations in Afghanistan exemplify this tendency. For instance, the Human Rights Watch report on the conflict, Troops in Contact, asserts that "[ $\mathrm{t}]$ he cases described here raise concerns as to whether the attacking forces acted in accordance with their obligation under the laws of war to exercise 'constant care to spare the civilian population' and take 'all feasible precautions' to minimize loss of civilian life." 83

Human Rights Watch displayed a sophisticated understanding of targeting procedures during the conflict. The organization found that "when aerial bombing is planned, mostly against suspected Taliban targets, US and NATO forces in Afghanistan have had a very good record of minimizing harm to civilians ...." 84 It explained,

[p]lanned attacks allow the US and NATO to use civilian risk mitigation procedures, including formal risk estimates to model and minimize civilian casualties. This includes a "pattern of life analysis," which looks for civilians in the area for hours or days before an attack using "eyes on the target" ranging from ground observers to technical reconnaissance. According to NATO Judge Advocate General (JAG) staff, the US and NATO also require positive visual identification of the target during a planned strike, allowing the pilot to look for civilians and call off an attack based on those observations. Planned strikes also allow the US and NATO to develop a target over time, thereby using far more detailed intelligence to understand who is and is not in the target area..$^{85}$

Most casualties were caused, by contrast, during non-preplanned strikes. These TIC situations occurred when US or coalition forces came upon the enemy unexpectedly. Although the rules of engagement provided that forces should withdraw when civilians were in the vicinity of an attack, doing so was not always possible. For instance, it might expose them to greater risks or the path of retreat may have been cut off by the enemy. The report also pointed to cases which "began as TICs but lasted for several hours or days, with airstrikes used to support small troop numbers on the ground resulting in civilian deaths." 86

Human Rights Watch expressed numerous concerns about such engagements. With regard to TICs that developed into prolonged battles, the organization opined that the resulting civilian casualties "suggest[ed] that the US is not taking all feasible precautions during prolonged battles, including using adequate forces 
to minimize civilian harm, employing low-collateral damage bombs, and positively identifying the locations of combatants and civilians." ${ }^{87}$ It also suggested that while preplanned attacks involved intricate procedures to determine the presence of civilians, during a TIC the "tactical collateral damage assessment performed by the Joint Terminal Attack Controller (JTAC), a service member qualified in directing airstrikes on the ground[,] is one of the only checks done, and, of necessity, such assessments often are made under the stress of hostile fire." 88

While Troops in Contact is the best report produced by the organization on international humanitarian law in recent conflicts, ${ }^{89}$ its analysis of the precautions in attack norms misses several key points. As it did in its report on Operation Iraqi Freedom, Human Rights Watch appears to have imposed a rebuttable presumption that collateral damage evidences a failure to take sufficient precautions in attack. This shifts the burden to the attacker, who by this approach must demonstrate that it complied with precautions norms. That this is so is illustrated by a flawed tendency to allege failure to take feasible precautions without identifying or developing those which were presumably available, but ignored.

"Feasible precautions" have been defined as "precautions which are practicable or practically possible taking into account all circumstances ruling at the time, including humanitarian and military considerations." ${ }^{90}$ Consider the suggestions cited above. Albeit reasonable in the abstract, there is no support in the report for the proposition that they were feasible in the sense of being practical in the circumstances at hand. For instance, were additional troops on hand that could have been deployed to minimize civilian harm? Or were low-collateral-damage bombs readily available, either at bases from which aircraft launched or aboard the attacking aircraft (since many attacks were conducted by aircraft to which targets were passed while already airborne)? As to the fact that only JTACs generally had eyes on target, one must query what the alternative might have been. What seems to have been missed is that, as a matter of law, the feasible-precautions-in-attack requirements only apply when there are practical alternatives available to the attacker. The burden of demonstrating non-compliance lies with those asserting violation of the requirements, not the forces executing the attack.

In contrast to the LIT criterion for engagement, self-defense was much clearer, since it is a standard to which US and other forces train and with which they are, therefore, familiar. Self-defense presents no status issues because anyone against whom self-defense is necessary can be engaged. Further, it poses no directparticipation-in-hostilities concerns, because only those who are actually attacking, or about to attack, are liable to being engaged defensively. Accordingly, neither the scope nor the timing debates infecting direct-participation analysis, and, correspondingly, the LIT criterion, surface. 
Be that as it may, even self-defense proved troublesome in Afghanistan. As is often the case with application of rules of engagement, mission accomplishment standards tended to slip into application of self-defense principles. ${ }^{91}$ The condition precedent for acting in self-defense is either a hostile act or a demonstration of hostile intent..$^{92}$ For US forces, this standard is codified in the Standing Rules of Engagement. Both criteria reflect the self-defense concept of military necessity, by which force may only be used if lesser means of addressing the threat are likely not to suffice.

In preparing for combat in Afghanistan, "considerable time and effort was spent attempting to create training packages aimed at developing a specific level of identification before either returning fire or taking other actions in response to a hostile act or demonstration of hostile intent." ${ }^{\prime 93}$ Identification has no place in self-defense situations, other than to locate the source of the hostile act or demonstration of hostile intent. It is instead an element of mission accomplishment rules of engagement, by which forces are authorized to attack combatants and direct participants only once they have been reliably identified as such.

It is well-accepted that intermingling mission accomplishment and self-defense notions in rules of engagement risks causing those who need to act in self-defense to hesitate, thereby endangering themselves and others in their units. Moreover, US training emphasizes that there is no need to seek higher approval in self-defense situations, for delay may impede the ability of troops to defend themselves. It is only in mission accomplishment rules of engagement that engagement approval levels appear. Conflating the two types of rules of engagement can confuse troops at the tactical level, causing them to act precipitously when they should be seeking higher approval in a mission accomplishment engagement.

A further self-defense complication derived from the fact that US and NATO forces operated in the same theater. Both used "hostile intent" as a criterion for employing airpower in defensive operations employing airpower. ${ }^{94}$ However, NATO defined the term as "manifest and overwhelming" force, whereas the US standard was "the threat of imminent use of force." 95 In other words, the NATO standard placed greater emphasis on the necessity criterion of self-defense and was more restrictive temporally. Employing the same term differently created confusion regarding the availability of air support in TIC situations, especially when US and NATO forces were supporting each other. It also created an impression that the US forces were quick to pull the trigger. As one ambassador in the country told Human Rights Watch, "[s]ome Afghans think the US is worse than the Russians. The problem is in the TIC they call in air support in a hurry, and special forces go too far on the ground and call in airstrikes too often. There is a cultural problem 
with the US-they are cowboys. ${ }^{96}$ Since counterinsurgencies seek support of the population, such perceptions, whether correct or not, prove costly.

Finally, the mere notion of a self-defense rule of engagement is misplaced in armed conflicts. This is so not only because combatants are always lawful targets, but also due to the fact that the concept of direct participation already permits engaging anyone who is attacking or about to attack. The debate over the scope of direct participation has no bearing in this regard; all sides agree that acts which constitute a hostile act or a demonstration of hostile intent in the self-defense sense qualify as acts of direct participation. The controversy over the "for such time" criterion is equally irrelevant, since the term undeniably includes the period when an attack is imminent or under way (the self-defense period).

Consequently, the only legally relevant circumstance for self-defense during an armed conflict is defense against those who do not meet the scope requirements of direct participation, specifically that requiring a belligerent nexus to the hostilities. Expanding self-defense beyond such situations by giving it a central role in engagement guidance was, therefore, unusual as an operational matter and unnecessary as a matter of law. Doing so represented yet another policy and operational decision ratcheting back what was allowed by international humanitarian law.

\section{Concluding Thoughts}

What is fascinating about the application of IHL in Afghanistan (and other recent conflicts) is that its foundational premise seems to have been turned on its head. International humanitarian law is designed for classic attrition warfare, where each side tries to so wear down the enemy forces that they can no longer continue fighting. The St. Petersburg Declaration principle that law fixes the "limits at which the necessities of war ought to yield to the requirements of humanity" comported neatly with warfare along such lines.$^{97}$ Both sides sought to avoid excessive restrictions on their military actions, but both also wanted to ensure the protection of their civilian populations. Military necessity and civilian harm were counterpoised in a zero-sum game.

However, this traditional balance began to be stressed by the emergence of coercive warfare, in which the objective is not to defeat the enemy, but rather to affect a decisionmaker's calculations. NATO's air campaign in 1999 (Operation Allied Force), during which the goal was to convince Slobodan Milosevic to stop slaughtering the Kosovar Albanians and return to the negotiating table, best illustrates coercive warfare in the contemporary context. ${ }^{98}$ The dilemma was that some of those assets, the destruction of which would most effectively have such effects (such as property owned by the State's leader), qualified as protected civilian 
Targeting and International Humanitarian Law in Afghanistan

property under international humanitarian law. The ensuing calls for a relaxation of the lex lata should have come as no surprise. ${ }^{99}$

Counterinsurgency warfare, in that it seeks to win hearts and minds, constitutes "persuasive" warfare, that is, warfare designed to influence the population of the State in which an insurgency is under way, and, to a lesser extent, international public and governmental opinion. Since collateral damage hinders military operations by undercutting domestic and international support and by increasing insurgent strength, strict compliance with IHL norms actually complements military necessity. Accordingly, as in Afghanistan, counterinsurgent forces often adopt restrictions on their operations that far outstrip those found in the law. Humanitarians and counterinsurgency warfighters paradoxically find themselves in lockstep.

Their perspectives on the practices may, nevertheless, conflict. Although the restrictions originate as context-specific operational and policy choices, humanitarians tend to style them as normative. As a matter of law, the crux of the issue is whether such restrictions comprise State practice bearing on the emergence of customary international law norms.

The ICRC's Customary International Humanitarian Law study notes that "both physical and verbal acts of States constitute practice that contributes to the creation of customary international law. Physical acts include, for example, battlefield behavior.... Verbal acts include military manuals ... instructions to armed and security forces, military communiqués during war ...." ${ }^{100}$ But what must be emphasized is that State practice matures into customary law only when it evidences opinio juris sive necessitatis, a belief on the part of States engaging in said practice that it is legally obligatory. ${ }^{101}$ Clearly, the extensive restrictions placed on US and coalition forces in Afghanistan did not result from legal concerns, but rather apprehension that even legal collateral damage would prove counterproductive in the specific context of Afghanistan. In other words, they did not rise to the level of State practice which would evidence the emergence of international humanitarian law norms more restrictive than those already extant.

Be that as it may, warfighters, commentators and judge advocates often conflate the distinction between humanitarian law and rules of engagement (and other engagement mandates). The latter include not only elements of law, but also operational and policy dictates. Because ROE are the actual norms applicable on a battlefield, many observers lose sight of the difference, thereby distorting assessments of State practice. ${ }^{102}$ One can imagine that the CDEM process, for instance, might foster expectations that greater collateral damage requires a higher level of approval authority. Similarly, the LIT concept risks suggesting that there is no longer any military necessity in declaring combatants hostile, as permitted in IHL. 
Ultimately, the conduct of hostilities in Afghanistan illustrated a shift from law toward legitimacy. As governments, non-governmental organizations, academics and others raise expectations, there is decreasing emphasis on strict legal analysis. In Afghanistan, for instance, authorization to conduct attacks which would otherwise comport with the proportionality principle was sometimes denied as risking "bad press" or negative communicative consequence. The requirement to take feasible precautions in attack seems to be slowly slipping toward a standard of all possible precautions.

Clearly, law is playing a lesser role in targeting than it has in past conflicts. This lesson has not been lost on enemy forces, who increasing employ lawfare- the use of law as a "weapon" employed to create the impression, correct or not, that an opponent acts lawlessly, thereby undercutting support for the war effort. ${ }^{103}$ In the face of this strategy, there is even greater motivation for operating at levels of caution far exceeding the IHL's mandates. But doing so only exacerbates the blurring of legal, policy and operational practices.

Prosecuting a conflict to the limit of the law to prevent erosion of the military necessity aspect of international humanitarian law is self-evidently not the answer. At least in a counterinsurgency doing so would sacrifice victory on the altar of principle. Nevertheless, rules of engagement and other targeting restrictions should be crafted in a way that reflects the content, structure, function and accepted terminology of this body of law. Afghanistan should serve as a warning that understanding and communicating the difference between law, on the one hand, and operational and policy choices, on the other, remains imperative.

\section{Notes}

1. Protocol Additional to the Geneva Conventions of 12 August 1949, and Relating to the Protection of Victims of International Armed Conflicts art. 49.1, June 8, 1977, 1125 U.N.T.S. 3, reprinted in DOCUMENTS ON THE LAWS OF WAR 422 (Adam Roberts \& Richard Guelff eds., 3d ed. 2000) [hereinafter AP I].

2. The accepted definition of international armed conflict is found in Common Article 2 of the four 1949 Geneva Conventions: "[A]11 cases of declared war or of any other armed conflict which may arise between two or more [States], even if the state of war is not recognized by one of them." Convention for the Amelioration of the Condition of the Wounded and Sick in Armed Forces in the Field art. 2, Aug. 12, 1949, 6 U.S.T. 3114, 75 U.N.T.S. 31 [hereinafter GC I]; Convention for the Amelioration of the Condition of Wounded, Sick and Shipwrecked Members of Armed Forces at Sea art. 2, Aug. 12, 1949, 6 U.S.T. 3217, 75 U.N.T.S. 85 [hereinafter GC II]; Convention Relative to the Treatment of Prisoners of War art. 2, Aug. 12, 1949, 6 U.S.T. 3316, 75 U.N.T.S. 135 [hereinafter GC III]; and Convention Relative to the Protection of Civilian Persons in Time of War art. 2, Aug. 12, 1949, 6 U.S.T. 3516, 75 U.N.T.S. 287 [hereinafter GC IV]: all reprinted in id. at 197, 222, 244 and 301, respectively. 


\section{Targeting and International Humanitarian Law in Afghanistan}

3. See, e.g., Derek Jinks, The Applicability of the Geneva Conventions to the "Global War on Terrorism," 46 VIRGINIA JOURNAL OF INTERNATIONAL LAW 165, 177-90 (2005). In 2002, President George Bush concluded that the conflict with Al Qaeda was "international in scope." Memorandum from George W. Bush to the Vice President et al., Subject: Humane Treatment of Al Qaeda and Taliban Detainees para. 2(c) (Feb. 7, 2002), reprinted in THE TORTURE PAPERS: THE ROAD TO ABU GHRAIB 134 (Karen J. Greenberg \& Joshua Dratel eds., 2005). Four years later, the Supreme Court disagreed, finding a conflict with transnational terrorists to be "not of an international character," as that term is employed in Common Article 3 to the 1949 Geneva Conventions. Hamdan v. Rumsfeld, 126 S.Ct. 2749, 2795-97 (2006). The International Committee of the Red Cross takes the position that transnational terrorism, absent a nexus to either an international or non-international armed conflict, fails to qualify as an armed conflict in the first place. See INTERNATIONAL COMMITTEE OF THE RED CROSS, INTERNATIONAL HUMANITARIAN LAW AND THE CHALLENGES OF CONTEMPORARY ARMED CONFLICTS 7-8, available at http://www icrc.org/Web/eng/siteeng0.nsf/htmlall/ihl-30-international-conference-101207/\$File/IHL-challenges -30th-International-Conference-ENG.pdf [hereinfter IHL and the Challenges of Contemporary Armed Conflicts].

4. Despite its illegitimacy, and non-recognition by most States, the Taliban constituted the de facto government of Afghanistan in that it controlled the greatest amount of territory and generally exercised the normal functions of governance. As noted by Yoram Dinstein, "[n]o formal recognition is required by a belligerent State as to the statehood of the opposing side. As long as the adversary satisfies objective criteria of statehood under international law, any armed conflict between two belligerent Parties would be characterized as inter-State." YORAM DINSTEIN, THE CONDUCT OF HOSTILITIES IN THE LAW OF INTERNATIONAL ARMED CONFLICT 16 (2004). Therefore, in humanitarian law terms, the conflict in Afghanistan between the Taliban forces (and organized armed groups supporting the Taliban) and the US-led coalition was an international armed conflict.

5. S.C. Res. 1419, U.N. Doc. S/RES/1419 (June 26, 2002). Additional Protocol II to the Geneva Conventions, which addresses non-international armed conflict, does not apply to the conflict because Afghanistan is not a party to the instrument; even if it was, the conflict would not meet the threshold criteria set forth in Article 1.1. Protocol Additional to the Geneva Conventions of 12 August 1949, and Relating to the Protection of Victims of Non-International Armed Conflicts art. 1.1, June 8, 1977, 1125 U.N.T.S. 609, reprinted in DOCUMENTS ON THE LAWS OF WAR, supra note 1 , at 483 . However, the conflict does meet the threshold criteria of Common Article 3, to which Afghanistan is a party, as an "armed conflict not of an international character," as well as those contained in customary international law. GC I, II, III, IV, supra note 2, art. 3; MICHAEL N. SCHMITT, CHARLES H.B. GARRAWAY \& YORAM DINSTEIN, THE MANUAL ON THE LAW OF NON-INTERNATIONAL ARMED CONFLICT, Rule 1.1.1 and accompanying commentary (2006), reprinted in 36 ISRAEL YEARBOOK ON HUMAN RIGHTS (2006) (Special Supplement), available at http://www.michaelschmitt.org/images/Manual\%5B1\%5D.Final.Brill..pdf [hereinafter NIAC Manual].

6. This is the position taken by the International Committee of the Red Cross (ICRC). See IHL and the Challenges of Contemporary Armed Conflicts, supra note 3 , at 8 . However, some experts see a continuing international armed conflict, existing beside the non-international one, with Al Qaeda and related transnational terrorist groups.

7. AP I, supra note 1, art. 48. In the Tadic case, the International Criminal Tribunal for the former Yugoslavia Appeals Chamber held that the principle of distinction, which lies at the heart of the law of targeting, applies in non-international armed conflict. By the decision, customary rules had developed to govern "internal strife," covering 
Michael N. Schmitt

such areas as protection of civilians from hostilities, in particular from indiscriminate attacks, protection of civilian objects, in particular cultural property, protection of all those who do not (or no longer) take active part in hostilities, as well as prohibition of means of warfare proscribed in international armed conflicts and ban of certain methods of conducting hostilities.

Prosecutor v. Tadic, Case No. IT-94-1, Decision on Defence Motion for Interlocutory Appeal on Jurisdiction para. 127 (Oct. 2, 1995). The Tribunal cited General Assembly Resolution 2444, which recognized the "necessity of applying basic humanitarian principles in all armed conflict." Id., para. 110, citing G.A. Res. 2444 (XXIII), U.N. Doc. A/7218 (Dec. 19, 1968), Respect for Human Rights in Armed Conflicts, reprinted in THE LAWS OF ARMED CONFLICT 511 (Dietrich Schindler \& Jiri Toman eds., 4th ed. 2004). The United States later recognized the Resolution as "declaratory of existing customary international law." Letter from J. Fred Buzhardt, General Counsel of the Department of Defense, to Senator Edward Kennedy (Sept. 22, 1972), excerpted in A. Rovine, Contemporary Practice of the United States Relating to International Law, 67 AMERICAN JOURNAL OF INTERNATIONAL LAW 118, 122 (1973). See also NIAC Manual, supra note 5, at 11; CUSTOMARY INTERNATIONAL HUMANITARIAN LAW 25-29 (Rule 7 and accompanying commentary) (Jean-Marie Henckaerts \& Louise Doswald-Beck eds., 2005) [hereinafter CIHLS]; COMMENTARY ON THE ADDITIONAL PROTOCOLS OF 8 JUNE 1977 TO THE GENEVA CONVENTIONS OF 12 AUGUST 1949 para. 4761 (Yves Sandoz, Christophe Swinarski \& Bruno Zimmermann eds., 1987) [hereinafter AP I Commentary].

8. The US Army has cited complexity as a major factor in future operations. In particular, it points to three especially relevant manifestations: complex physical terrain, complex human terrain and complex informational terrain.

In the face of overwhelming U.S. combat power, future adversaries can be expected to conduct operations more frequently from the shelter of complex physical terrain (urban, jungle/forest, and mountain). Such terrain typically comprises a mosaic of open patches and highly restrictive terrain, with the potential to minimize exposure to superior firepower, inflict higher U.S. casualties, and prolong the conflict. Urban defenses, in particular, will tend to reduce U.S. advantages in overhead information collection, tactical mobility, and long-range precision fires, instead placing a premium on dismounted maneuver, direct fires, ground reconnaissance, HUMINT, and the troop strength needed to conduct them.

An urban setting also invites adversaries to exploit public sensitivities to collateral damage and civilian casualties, and tends to magnify the perceived costs of protracted conflict....

Complex human terrain exists where numerous population groups coexist in the same physical space - often a city or an urbanized area. These might include ethno-linguistic groups, political factions, tribes or clans, religious sects, or ideological movements. Identification of combatants in complex human terrain is extraordinarily difficult; applying force in such an environment imposes a high risk of counterproductive or unintended consequences.

Finally, complex informational terrain is the multiple sources or transmission paths for communications, data, or information-including news media. A force operating in complex informational terrain will not have the ability to control information flow.

U.S. Army Training and Doctrine Command, TRADOC Pam. 525-3-0, The Army in Joint Operations: The Army's Future Force Capstone Concept 2015-2024, at 44 (2005). 


\section{Targeting and International Humanitarian Law in Afghanistan}

9. For a general description of Afghanistan, see Central Intelligence Agency, The World Factbook, Afghanistan (2008), https://www.cia.gov/library/publications/the-world-factbook/ geos/af.html (last visited Mar. 11, 2009).

10. This approach reversed the standard tactic of ground forces driving the enemy into areas where it can be attacked by airpower. In Afghanistan, air attacks often did the opposite, with air forces driving the enemy into areas where it could be engaged by ground forces.

11. "An organized movement aimed at the overthrow of a constituted government through use of subversion and armed conflict." Chairman of the Joint Chiefs of Staff, Joint Publication 102, Dictionary of Military and Associated Terms (Apr. 12, 2001, as amended through Oct. 17, 2008), http://www.dtic.mil/doctrine/jel/doddict/ [hereinafter DoD Dictionary]. Security Council resolutions setting forth mandates on Afghanistan illustrate the counterinsurgency nature of operations. See, e.g., S.C. Res. 1386, U.N. Doc. S/RES/1386 (Dec. 20, 2001); S.C. Res. 1413, U.N. Doc. S/RES/1413 (May 20, 2002); S.C. Res. 1444, U.N. Doc. S/RES/1444 (Nov. 20, 2002); S.C. Res. 1510, U.N. Doc. S/RES/1510 (Oct. 13, 2003); S.C. Res. 1563, U.N. Doc. S/RES/1563 (Sept. 17, 2004); S.C. Res. 1623, U.N. Doc. S/RES/1623 (Sept. 13, 2005); S.C. Res. 1659, U.N. Doc. S/ RES/1659 (Feb. 15, 2006); S.C. Res. 1707, U.N. Doc. S/RES/1707 (Sept. 12, 2006); S.C. Res. 1746, U.N. Doc. S/RES/1746 (Mar. 23, 2007); S.C. Res. 1776, U.N. Doc. S/RES/1776 (Sept. 19, 2007); S.C. Res. 1817, U.N. Doc. S/RES/1817 (June 11, 2008); S.C. Res. 1833, U.N. Doc. S/RES/1833 (Sept. 22, 2008)

12. US Marine Corps \& US Special Operations Command, Multi-Service Concept for Irregular Warfare Version 2.0, USMC Combat Development Command and US Special Operations Command Center for Knowledge and Futures, at 5-6 (2006), available at http://www.dtic.mil/ cgi-bin/GetTRDoc?AD=ADA454228\&Location=U2\&doc=GetTRDoc.pdf.

13. Headquarters, Department of the Army \& Headquarters, Marine Corps Combat Development Command, FM 3-24/MCWP 3-33.5, Counterinsurgency, at 1-141-1-142 (2006), available at http://www.usgcoin.org/library/doctrine/COIN-FM3-24.pdf [hereinafter COIN Manual]. The manual was drafted in part by General David Petraeus, who presently commands US Central Command (CENTCOM). The command exercises responsibility over the conflicts in both Iraq and Afghanistan.

14. Id. at $1-150$.

15. Chairman of the Joint Chiefs of Staff, Joint Publication 3-0, Joint Operations, at II-1 (2006, incorporating change 1 (Feb. 13, 2008)), available at http://www.dtic.mil/doctrine/jel/ new_pubs/jp3_0.pdf.

16. Headquarters, Air Force Doctrine Center, AFDD 2-1.9, Targeting, at 35 (2006), available at http://www.dtic.mil/doctrine/jel/service_pubs/afdd2_1_9.pdf [hereinafter AFDD 2-1.9]. The target validation phase ensures vetted targets

achieve the effects and objectives outlined in a commander's guidance and are coordinated and deconflicted with agencies and activities that might present a conflict with the proposed action. It also determines whether a target remains a viable element of the target system. During the development effort, the targets may also require review and approval based on the sensitive target approval and review process, coordinated through the combatant commander to national authorities.

Id. at 34 .

17. The CDEM methodology is set forth in Chairman of the Joint Chiefs of Staff, CJCSM 3160.01B, Joint Methodology for Estimating Collateral Damage and Casualties for Conventional Weapons: Precision, Unguided and Cluster (Aug. 31, 2007). The document is "For Official Use Only" and unavailable to the public. For open-source discussions of the topic, see Colin H. Kahn, Boots on the Ground or Bolts from the Blue? Risks to Civilians from U.S. 
Michael N. Schmitt

Counterinsurgency Operations in Iraq and Afghanistan 3-4 (unpublished memo prepared for the Cornell University "Human Rights at War" Workshop, Nov. 9-10, 2007); DWIGHT A. ROBLYER, BEYOND PRECISION: ISSUES OF MORALITY AND DECISION MAKING IN MINIMIZING COLLATERAL CASUALTIES, PAPER FOR THE PROGRAM IN ARMS CONTROL, DISARMAMENT, AND INTERNATIONAL SECURITY 18 (2003), available at http://acdis.illinois.edu/assets/docs/246/ BeyondPrecisionIssuesofMoralityandDecisionMakinginMinimizingCollateralCasualties.pdf.

18. 1 Center for Law and Military Operations, Judge Advocate General's Legal Center and School, Lessons Learned from Afghanistan and Iraq, Major Combat Operations (11 September 2001-1 May 2003), at 84 (2004) [hereinafter 1 Lessons Learned].

19. The CENTCOM CDEM for both Operation Enduring Freedom and Operation Iraqi Freedom is illustrative. It sets forth a series of questions to be addressed during the CDEM process:

1. Can I positively identify the object or person I want to attack as a legitimate military target authorized for attack by the current rules of engagement?

2. Is there a protected facility (i.e. No Strike), civilian object or people, or significant environmental concern within the effects range of the weapon I would like to use to attack the target?

3. Can I avoid damage to that concern by attacking the target with a different weapon or with a different method of approach?

4. If not, how many people do I think will be injured/killed by my attack?

5. Do I need to call my higher commander for permission to attack this target? Id. at 103, citing US Central Command, Collateral Damage Estimation Policy and Methodology para. 2 (2003).

20. However, the law of targeting contains many unresolved issues. On some of them, see Michael N. Schmitt, Targeting, in PERSPECTIVES ON THE ICRC STUDY ON CUSTOMARY INTERNATIONAL HUMANITARIAN LAW 131 (Susan Breau \& Elizabeth Wilmshurst eds., 2007); Michael N. Schmitt, Fault Lines in the Law of Attack, in TESTING THE BOUNDARIES OF INTERNATIONAL HUMANITARIAN LAW 277 (Susan Breau \& Agnieszka Jachec-Neale eds., 2006).

21. AP I, supra note 1, art. 51; CIHLS, supra note 7, ch. 1; US Navy, Marine Corps \& Coast Guard, The Commander's Handbook on the Law of Naval Operations, NWP 1-14M/MCWP 512.1/COMDTPUB P5800.7A paras. 8.2.1, 8.2.2 (2007) [hereinafter NWP 1-14M]; UK MINISTRY OF DEFENCE, THE MANUAL OF THE LAW OF ARMED CONFLICT para. 5.32 (2004) [hereinafter British Manual]; NIAC Manual, supra note 5, Rules 2.1.1, 2.1.1.1 \& 2.1.1.2.

22. AP I, supra note 1, art. 52.2. "Nature" denotes intrinsic military significance, thereby including objects like ammunition depots, tanks, combat aircraft, headquarters or military barracks. "Location" refers to areas that have "special importance to military operations." The classic example is a mountain pass that can be blocked to foil the enemy's advance. When reliable intelligence or other information indicates that the enemy intends to use an object militarily in the future, the object qualifies as a military objective through "purpose." Finally, "use" means that the enemy is presently utilizing an object militarily. AP I Commentary, supra note 7, paras. 2020-24. See also British Manual, supra note 21, para. 4.4.

23. AP I, supra note 1, art. 51.3: "Civilians shall enjoy the protection afforded by this Section, unless and for such time as they take a direct part in hostilities." See also CIHLS, supra note 7, at 19 (Rule 6); NWP 1-14M, supra note 21, para. 8.2.2; British Manual, supra note 21, para. 5.3.2.

24. AP I, supra note 1 , arts. 51.4(a) \& 51.5(a). See also CIHLS, supra note 7, at 37 (Rule 11), 40 (Rule 12), 43 (Rule 13); British Manual, supra note 21, para. 5.24.

25. CIHLS, supra note 7, at 244 (Rule 71). See also AP I, supra note 1, arts. 51.4(b) \& (c); NWP 1-14M, supra note 21, para. 9.1.2; British Manual, supra note 21, para. 6.4. 


\section{Targeting and International Humanitarian Law in Afghanistan}

26. CIHLS, supra note 7, at 237 (Rule 70). See also AP I, supra note 1, art. 35.2; NWP 1-14M, supra note 21, para. 9.1.1; British Manual, supra note 21, para. 6.2.

27. Convention on Cluster Munitions, May 30, 2008, available at http://www.icrc.org/ihl .nsf/FULL/620? OpenDocument.

28. NWP 1-14M, supra note 21, para. 8.3.1. The requirement is codified in AP I, supra note 1, art. 57. See also CIHLS, supra note 7, ch. 5; British Manual, supra note 21, para. 5.32.

29. AP I, supra note 1, arts. 51.5(b) \& 57.2(b); CIHLS, supra note 7, ch. 4; NWP 1-14M, supra note 21, para. 8.3.1; British Manual, supra note 21, paras. 2.6-2.8.

30. The commentary to Article 51 suggests that damage which is "extensive" is not proportionate. AP I Commentary, supra note 7, para. 1980. See discussion in DINSTEIN, supra note 4, at $120-21$.

31. For a discussion of the incidents, see Sean D. Murphy, Contemporary Practice of the United States Relating to International Law, 96 AMERICAN JOURNAL OF INTERNATIONAL LAW 237, 247 (2002).

32. HuMAN RightS WATCH, TROOPS IN CONTACT 22 (2008) [hereinafter Troops IN CONTACT], citing e-mail communication from NATO Media Operations Center to Human Rights Watch (May 6, 2008).

33. Id. at 14 .

34. Karzai Denounces Reported Civilian Deaths from U.S., NATO Raids, Online NewsHour (May 2, 2007), http://www.pbs.org/newshour/updates/asia/jan-june07/afghanistan_05-02.html.

35. Headquarters United States Air Force, Operation Anaconda: An Airpower Perspective 42-43 (2005), available at http://www.af.mil/shared/media/document/AFD-060726-037.pdf.

36. "Directives issued by competent military authority that delineate the circumstances and limitations under which United States forces will initiate and/or continue combat engagement with other forces encountered." DoD Dictionary, supra note 11.

37. "A folder, hardcopy or electronic, containing target intelligence and related materials prepared for planning and executing action against a specific target." Id.

38. "A plan for a connected series of joint air operations to achieve the joint force commander's objectives within a given time and joint operational area." Id.

39. "An order to initiate military operations as directed." Id.

40. "An abbreviated form of an operation order issued as needed after an operation order to change or modify that order or to execute a branch or sequel to that order." Id.

41. "A measure employed by land or amphibious commanders to facilitate the rapid engagement of targets and simultaneously provide safeguards for friendly forces." Id.

42. A card distributed to soldiers bearing simple rules regarding the use of force and other matters.

43. 1 Lessons Learned, supra note 18 , at $86-88$. See generally AFDD 2-1.9, supra note 16 , at 94-95.

44. AP I, supra note 1, art. 51.3; CIHLS, supra note 7, at 19 (Rule 6); NWP 1-14M, supra note 21, para. 8.2.2; British Manual, supra note 21, para. 5.3.2. See also the reports of meetings of a group of international experts advising the ICRC on interpretive guidance regarding the notion of direct participation, available at http://www.cicr.org/Web/Eng/siteeng0.nsf/htmlall/participation -hostilities-ihl-311205. The guidance will be issued in 2009.

45. The United Nations Office of the High Commissioner for Human Rights issued what is effectively a model standard in 1990. The Basic Principles on the Use of Force and Firearms by Law Enforcement Officials provides that

[1] aw enforcement officials shall not use firearms against persons except in self-defense or defense of others against the imminent threat of death or serious injury, to prevent 
the perpetration of a particularly serious crime involving grave threat to life, to arrest a person presenting such a danger and resisting their authority, or to prevent his or her escape, and only when less extreme means are insufficient to achieve these objectives. In any event, intentional lethal use of firearms may only be made when strictly unavoidable in order to protect life.

U.N. Doc. A/CONF.144/28/Rev.1, prov. 9 (1990), available at http://www.unhchr.ch/html/menu3/ b/h_comp43.htm. On this and other use-of-force standards, see Michael N. Schmitt, Targeted Killings in International Law: Law Enforcement, Self-Defense and Armed Conflict, in INTERNATIONAL HUMANITARIAN LAW AND HUMAN RIGHTS LAW: TOWARDS A NEW MERGER IN INTERNATIONAL LAW 525 (Roberta Arnold \& Noelle Quenivert eds., 2008).

46. Chairman of the Joint Chiefs of Staff, CJCSI 3121.01B, Standing Rules of Engagement for US Forces, encl. A, paras. 2a \& 3 a (2005). A hostile act is "an attack or other use of force against the United States, US forces or other designated persons or property." Hostile intent is "the threat of imminent use of force" against the same entities. Id., paras. $3 \mathrm{e} \& \mathrm{f}$.

47. Various interviews with US military personnel with Operation Iraqi Freedom experience (May-Aug. 2008).

48. E-mail to author (June 17, 2008) (on file with author).

49. 1 Lessons Learned, supra note 18, at 100-102 and accompanying footnotes.

50. 2 Center for Law and Military Operations, Judge Advocate General's Legal Center and School, Lessons Learned from Afghanistan and Iraq, Full Spectrum Operations (2 May 200330 June 2004), at 137 (2004) [hereinafter 2 Lessons Learned].

51. 1 Lessons Learned, supra note 18 , at 96.

52. Id. This definition was the result of a series of meetings between operators and judge advocates at the CENTCOM level. The standard was applauded by some judge advocates, while criticized by others. Id. at $96 \mathrm{n} .59$.

53. Personal experience of author while Staff Judge Advocate, Operation Northern Watch, 1997.

54. A Marine after-action report expressed the frustration:

Upon 26th [Marine expeditionary unit (special operations capable)]'s arrival in the 5th Fleet [area of responsibility], I immediately began requesting guidance and clarification on the intent and meaning of this new concept, "likely and identifiable threat." My concerns were primarily that "likely and identifiable threat" was introducing an unfamiliar concept to our Marines immediately before the commencement of combat operations. I had trained our Marines on the concepts of hostile act, hostile intent and declared hostile, as well as other U.S. Standing ROE concepts, and was certain as to their ability to implement them in any context; however, on its face, "likely and identifiable threat" appeared to beg further elaboration and clarification.

[I]f judge advocates and commanders have relative difficulty in defining ROE terms, it goes without saying that the Marines charged with implementing the ROE will likely have similar difficulties.

1 Lessons Learned, supra note 18, at 100 n.77, citing Staff Judge Advocate, 26th Marine Expeditionary Unit (Special Operations Capable), After Action Report: Operation Enduring Freedom/Operation Swift Freedom (Mar. 22, 2002). Similar frustrations were expressed by others, including US Army judge advocates. Id.

55. Id. at $106 \mathrm{n} .91$, citing Memorandum, Dean L. Whitford, former Group Judge Advocate, 5 th Special Forces Group (Airborne), Staff Judge Advocate, Joint Special Operations Task Force- 


\section{Targeting and International Humanitarian Law in Afghanistan}

North (Task Force Dagger) (OEF), and Staff Judge Advocate, Combined Joint Special Operations Task Force-West and successor CJSOTF-Arabian Peninsula (OIF), for Major Daniel P. Saumur, Deputy Director, CLAMO, subject: Task Force Dagger OEF/OIF ROE AAR (June 14, 2004).

56. Id. at 100, citing Major Thomas A. Wagoner, Staff Judge Advocate, 15th Marine Expeditionary Unit (Special Operations Capable), After Action Report of the 15th MEU(SOC) West Pac 01 (2002).

57. This discussion is based on the experience of the author as a member of the group of experts participating in the ICRC effort to produce Interpretive Guidance on the Notion of Direct Participation. The ICRC Interpretive Guidance is expected to be released in March 2009.

58. Some controversy exists over whether the standard applies equally in non-international armed conflict. The author believes it should. Others would add a requirement that the individual be performing a "combat function."

59. AP I Commentary, supra note 7, para. 1944.

60. See, e.g., Michael N. Schmitt, Humanitarian Law and Direct Participation in Hostilities by Private Contractors or Civilian Employees, 5 CHICAGO JOURNAL OF INTERNATIONAL LAW 511, 535-36 (2005). The Israeli Supreme Court addressed the issue in Public Committee Against Torture in Israel et al. v. Government of Israel et al., HCJ 769/02, Judgment, para. 30 (Dec. 13, 2006), reprinted in 46 INTERNATIONAL LEGAL MATERIALS (2007), available at http://elyonl.court.gov.il/ files_eng/02/690/007/a34/02007690.a34.pdf. It rejected an argument that the "for such time" criterion was not customary law, but then proceeded to interpret it liberally.

61. The Vienna Convention provides that " $[\mathrm{a}]$ treaty shall be interpreted in good faith in accordance with the ordinary meaning to be given to the terms of the treaty in their context and in the light of its object and purpose." Vienna Convention on the Law of Treaties art. 31.1, opened for signature May 23, 1969, 1155 U.N.T.S. 331 . On the balance between military necessity and humanitarian concerns, see note 97 infra and accompanying text.

62. For criticism, see Schmitt, supra note 60, at 535-36. Lest the impact of the differing interpretations of direct participation on assessments of the appropriateness of LIT cause excess concern, it is important to emphasize that under both approaches (and LIT) an individual seeking temporary sanctuary in an inhabited area during an operation still qualifies as an attackable direct participant if the mission in question is ongoing.

63. Any concern that it is overly liberal would have to be tempered by the fact that the decision not to declare forces hostile already meant that operations in Afghanistan commenced with a higher standard than that required in IHL.

64. NWP 1-14M, supra note 21, para. 8.2.2. Note that the United States does not see the same rule regarding objects as customary in nature, for it risks shifting the burden as to determining the precise use of an object to the attacker from the person controlling the object. See US DEPARTMENT OF DEFENSE, FINAL REPORT TO CONGRESS: CONDUCT OF THE PERSIAN GULF WAR 616 (1992).

65. AP I, supra note 1, art. 50.1.

66. AP I Commentary, supra note 7, para. 1921.

67. Statement made by the United Kingdom at time of ratification, reprinted in DOCUMENTS ON THE LAWS OF WAR, supra note 1, at 510-11.

68. CIHLS, supra note 7 , at 24.

69. Author interview with judge advocate responsible for providing legal advice in such situations (May 2008).

70. Operation Anaconda, supra note 35 , at 40.

71. Anaconda was the first operation to involve significant US conventional ground forces.

72. AP I, supra note 1 , art. 57. 
73. COIN Manual, supra note 13, para. 7-32.

74. TROOPS IN CONTACT, supra note 32 , at 25-28.

75. AP I, supra note 1, art. 51.7; CIHLS, supra note 7, at 337 (Rule 97); NWP 1-14M, supra note 21, para. 8.3.2; British Manual, supra note 21, para. 15.14.2; NIAC Manual, supra note 5, para. 2.3.8.

76. But see DINSTEIN, supra note 4, at 131 , arguing that "the test of excessive injury must be relaxed."

77. AP I, supra note 1, art. 51.8. On human shields, see generally Michael N. Schmitt, Human Shields and International Humanitarian Law, 38 ISRAEL YEARBOOK ON HUMAN RIGHTS 17 (2008).

78. But all sides of the debate agree it is a factor in determining whether precautions are feasible.

79. In terms of the quantum of advantage, the ICRC Commentary notes that "it is not legitimate to launch an attack which only offers potential or indeterminate advantages." AP I Commentary, supra note 7, para. 2024.

80. See DINSTEIN, supra note 4, at 85-86; Schmitt, Fault Lines, supra note 20, at 295.

81. The small-diameter bomb is a guided munition that relies on the Global Positioning System of satellites to provide navigation to target. Because it is accurate, it does not need the explosive force that would otherwise be required to ensure destruction of the target. Its small size (currently in the $250 \mathrm{lb}$. class) reduces the likelihood of collateral damage. Factsheet, GBU-39B Small Diameter Bomb, Air Force Link, http://www.af.mil/factsheets/factsheet.asp?id=4500 (last visited Mar. 11, 2009). An upgrade replaces the steel casing with a composite casing to reduce the fragmentation effects of the weapon. Small Diameter Bomb/Small Smart Bomb, GlobalSecurity.org, http://www.globalsecurity.org/military/systems/munitions/sdb.htm (last visited Mar. 11, 2009).

82. See, e.g., Human Rights Watch, OfF TARget: THE CONDUCT OF THE WAR AND CiVILIAN CASUALTIES IN IRAQ 21-22, 40 (2003). For a discussion of the report's conclusion on precautions in attack, see Michael N. Schmitt, The Conduct of Hostilities During Operation Iraqi Freedom, 6 YEARBOOK OF INTERNATIONAL HUMANITARIAN LAW 90-92 (2003).

83. TROOPS IN CONTACT, supra note 32 , at 4 .

84. Id. at 29. Doctrine distinguishes among three types of targeting. Deliberate targeting is that which is preplanned (scheduled). Dynamic targeting occurs when a target was not anticipated or when, although anticipated, it was not identified in sufficient time to perform deliberate mission planning. Time-sensitive targeting occurs when there is a need for an immediate response because of a threat to friendly forces or in cases involving important lucrative fleeting targets. AJP-3.9, Allied Joint Doctrine for Targeting (2008).

85. TROOPS IN CONTACT, supra note 32 , at 29.

86. Id. at 30 .

87. Id.

88. Id. A life-pattern analysis looks at the pattern of civilian activity in the target area in an effort, for instance, to determine the times at which a strike will risk the least incidental injuries to civilians.

89. For a discussion of the organization's earlier report on Iraq, see Schmitt, supra note 82.

90. Protocol on Prohibitions or Restrictions on Use of Mines, Booby Traps and Other Devices art. 3(1), Oct. 10, 1980, as amended May 3, 1996, 2048 U.N.T.S. 133, reprinted in DoCUMENTS ON THE LAWS OF WAR, supra note 1, at 536.

91. Mission accomplishment rules of engagement are guidelines for performing an assigned mission, as distinct from those relating to defense of oneself and the force. For instance, mission 


\section{Targeting and International Humanitarian Law in Afghanistan}

accomplishment rules of engagement would establish guidelines for the conduct of a preplanned attack.

92. See definitions at note 46 supra.

93. 2 Lessons Learned, supra note 50, at 131, citing, for Operation Enduring Freedom, CJCS Message (S) $212315 \mathrm{Z}$ NOV 01, para. 3.H, and, for Operation Iraqi Freedom, USCENTCOM Message (S/REL AUS/GBR/USA) 121917Z MAR 03, para. 3.J.

94. TROOPS IN CONTACT, supra note 32, at 31 .

95. Id.

96. Id. at 32, citing Human Rights Watch interview with an ambassador (name withheld) in Kabul (July 22, 2007).

97. St. Petersburg Declaration Renouncing the Use, in Time of War, of Explosive Projectiles Under 400 Grammes Weight, Nov. 29, 1868, 138 Consol. T.S. 297, reprinted in DOCUMENTS ON THE LAWS OF WAR, supra note 1, at 54.

98. On coercive strategies, also labeled compellance strategies, see Michael N. Schmitt, Targeting and Humanitarian Law: Current Issues, 34 ISRAEL YEARBOOK ON HUMAN RIGHTS 59, 6069 (2004).

99. See, e.g., Charles J. Dunlap Jr., The End of Innocence: Rethinking Noncombatancy in the Post-Kosovo Era, STRATEGIC REVIEW, Summer 2000, at 14.

100. CIHLS, supra note 7, at xxxii. This approach has been criticized as overbroad by the United States. Letter from John B. Bellinger III, Legal Adviser, US Department of State, and William J. Haynes, General Counsel, US Department of Defense, to Dr. Jacob Kellenberger, President, International Committee of the Red Cross (Nov. 3, 2006), 46 INTERNATIONAL LEGAL MATERIALS 514 (2007).

101. Article 38 of the Statute of the International Court of Justice is universally accepted as a restatement of the sources of international law. Paragraph 1(b) includes "international custom, as evidence of a general practice accepted as law" in such sources. Statute of the International Court of Justice art. 38(1), June 26, 1945, 59 Stat. 1055, 33 U.N.T.S. 993 . According to the International Court of Justice,

[n] ot only must the acts concerned amount to a settled practice, but they must also be such, or be carried out in such a way, as to be evidence of a belief that this practice is rendered obligatory by the existence of a rule of law requiring it. The need for such a belief, i.e., the existence of a subjective element, is implicit in the very notion of the opinio iuris sive necessitatis. The States concerned must therefore feel that they are conforming to what amounts to a legal obligation.

North Sea Continental Shelf (F.R.G. v. Den.; F.R.G. v. Neth.), 1969 I.C.J. 3, 44 (Feb. 20). See also Continental Shelf (Libya v. Tunis.), 1985 I.C.J. 13, 36 (June 3). For an excellent summary of the nature and sources of customary international humanitarian law, see Jean-Marie Henckaerts, Study on Customary International Humanitarian Law: A Contribution to the Understanding and Respect for the Rule of Law in Armed Conflict, 87 INTERNATIONAL REVIEW OF THE RED CROSS 175 (2005). On customary international law generally, see Yoram Dinstein, The Interplay between Customary International Law and Treaties, 322 RECUEIL DES COURS 246 (2006).

102. On the law relevant to precision attacks, see Michael N. Schmitt, Precision Attack and International Humanitarian Law, 87 INTERNATIONAL REVIEW OF THE RED CROSS 445 (2005).

103. On lawfare, see Charles Dunlap Jr., Law and Military Interventions: Preserving Military Values in 21st Century Conflicts (Working Paper, Harvard Kennedy School, Carr Center for Human Rights Policy, 2001), available at http://www.hks.harvard.edu/cchrp/programareas/ nshr_publications.php (follow "Working Papers Volume 1 Part 1" hyperlink). In Iraq, for instance, insurgents quickly learned that coalition forces employ counter-battery fire against mortar 
Michael N. Schmitt

attacks. They, thus, adopted a "shoot and scoot" tactic in which they fired from an area containing civilians (often with little likelihood of hitting coalition forces), hoping the coalition response would cause civilian deaths and injuries that would generate negative public and international reaction. Author interviews with senior US Marine Corps and Army officers (June 2008). Hezbollah employed the same tactics in Lebanon in 2006, firing Katyusha rockets from populated areas in the hope of baiting the Israelis into a response. See Israel Ministry of Foreign Affairs, Hizbullah's Exploitation of Lebanese Population Centers and Civilians: Photographic Evidence (2006), http://www.mfa.gov.il/MFA/MFAArchive/2000_2009/2006/Operation+Change +of+Direction+Video+Clips.htm. 